\title{
Limb shaking
}

\section{Video EEG report in a patient with neurolupus but no carotid stenosis}

自

\section{Figure 1 Patient's CT angiography and MRI}
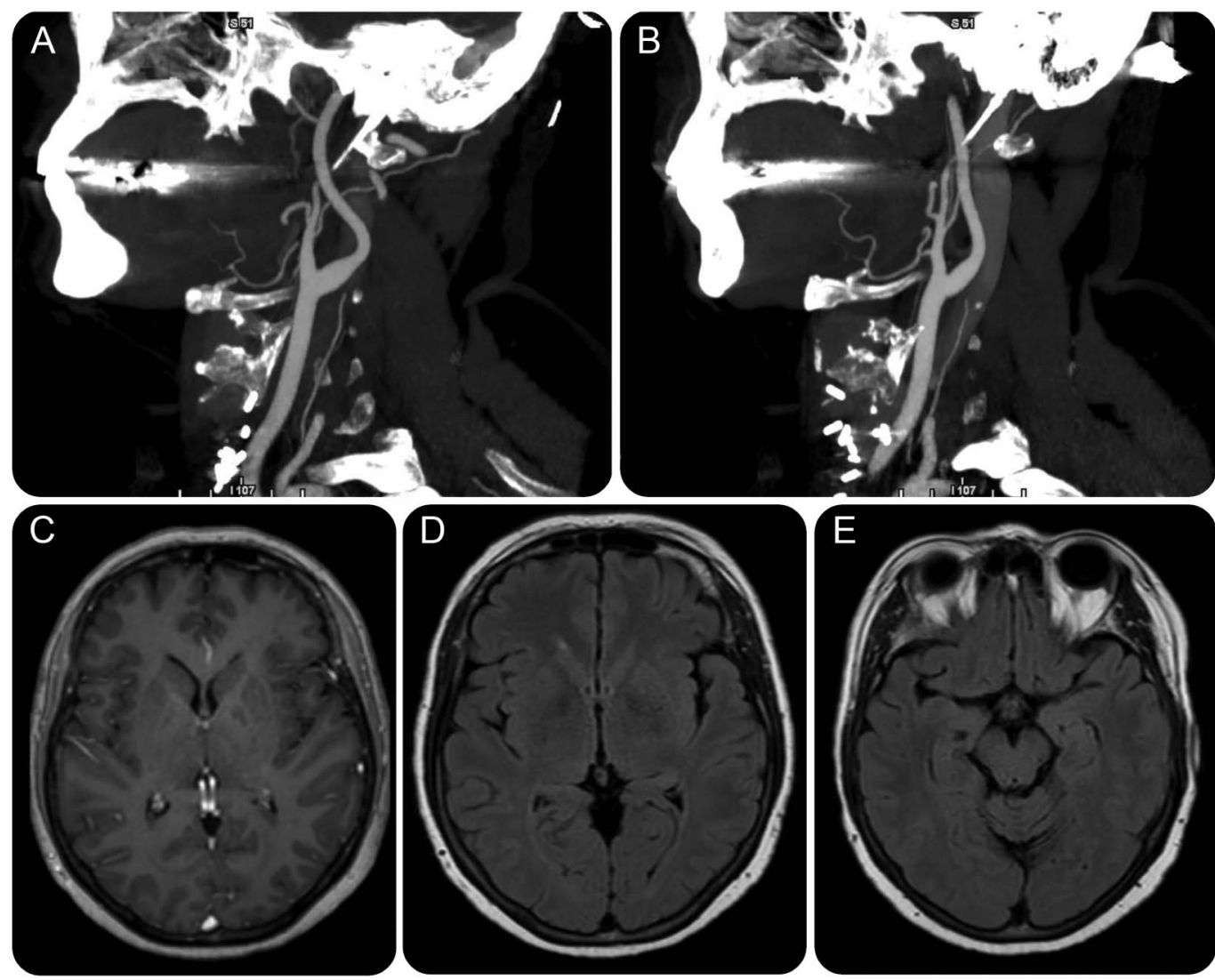

Cerebral angiography does not reveal any occlusive lesion of the left (A) or right (B) carotid arteries. Brain MRI showed nonspecific supratentorial hyperintensities on T1 gadolinium (C) and T2 fluid-attenuated inversion recovery (D and E).

Limb shaking can occur in patients with carotid occlusive lesions. ${ }^{1,2}$ A 55 -year-old woman with CNS lupus presented with episodes of upper limb jerky movements, preceded by generalized weakness provoked by prolonged upright posture. Orthostatic hypotension testing was negative. Brain MRI showed nonspecific supratentorial hyperintensities, and CT angiography showed no carotid stenosis (figure 1). Video EEG recorded the change to the upright position and showed bilateral slow activity during the attack (figure 2; video at Neurology.org). In the absence of carotid stenosis, limb shaking might be explained by cerebral hypoperfusion due to small vessel angiopathy in CNS lupus.

Natalia M. Moll, MD, PhD, Karine Mazodier, MD, Fabrice Bartolomei, MD, PhD, Agnes Trebuchon, MD, PhD

Supplemental data at Neurology.org
From the Aix-Marseille Université (F.B., A.T.), INSERM, INS, Institut de Neurosciences des Systèmes, Marseille; APHM (N.M.M., F.B., A.T.), Hôpital de la Timone, Service de Neurophysiologie Clinique, Marseille; and APHM (K.M.), Hôpital de la Conception, Service de Médecine Interne, Marseille, France.

Author contributions: N.M. Moll: analysis and interpretation of data. K. Mazodier: acquisition of data. F. Bartolomei: analysis and interpretation of data, critical revision of manuscript for intellectual content. A. Trebuchon: acquisition of data, analysis and interpretation of data, study concept and critical revision of manuscript for intellectual content.

Study funding: No targeted funding reported. 
Figure 2 Ictal 24-electrode EEG

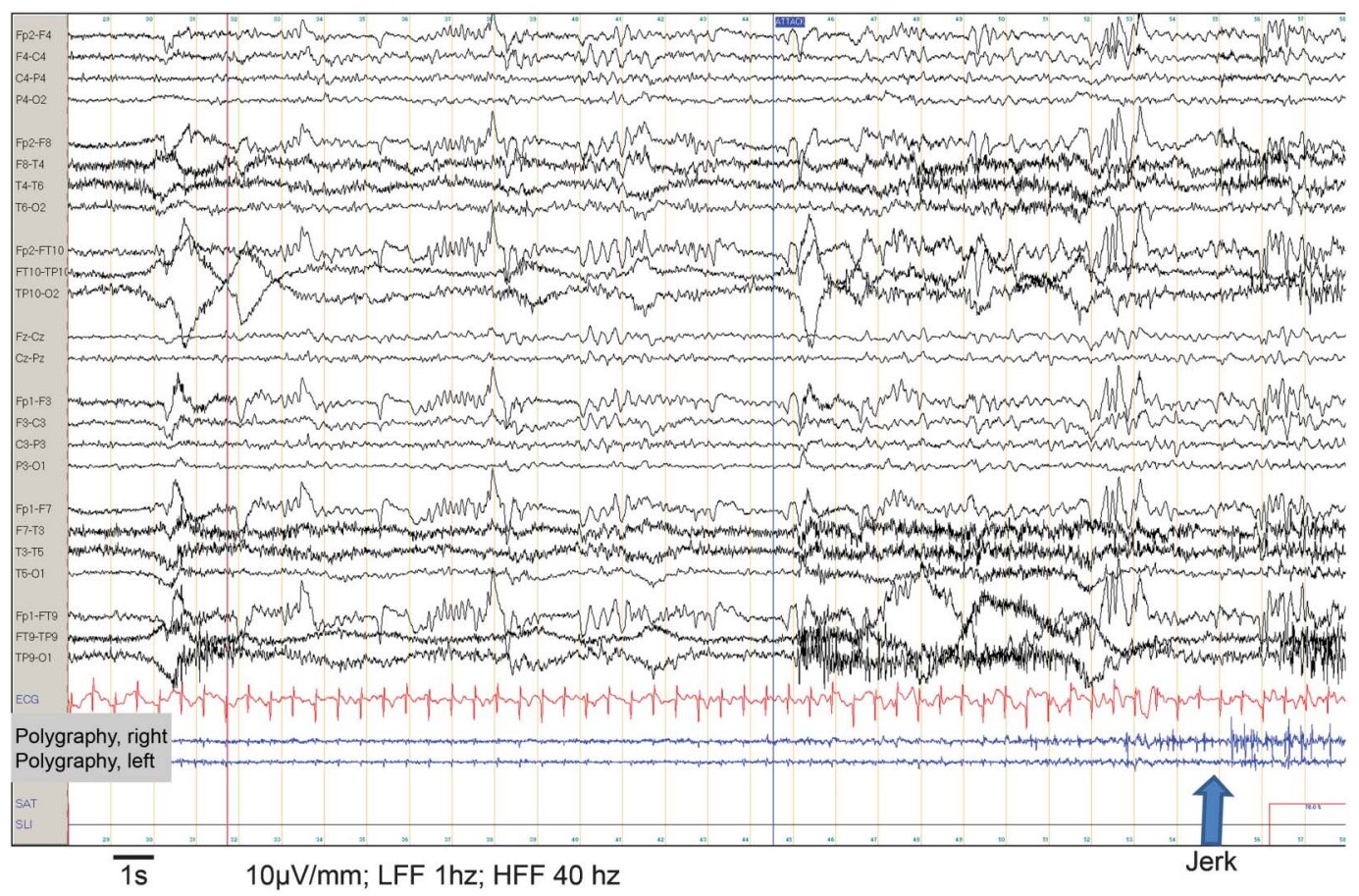

Normal electrical activity progressively transforms into bilateral slow waves corresponding to tau and delta rhythms consequent to onset of limb shaking.

Disclosure: The authors report no disclosures relevant to the manuscript. Go to Neurology.org for full disclosures.

Correspondence to Dr. Trebuchon: agnes.trebuchon@univ-amu.fr

1. Baquis GD, Pessin MS, Scott RM. Limb shaking: a carotid TIA. Stroke 1985;16:444-448.

2. Siniscalchi A, Gallelli L, Malferrari G, De Sarro G. Limb-shaking transient ischemic attack associated with focal electroencephalography slowing: case report. J Vasc Interv Neurol 2012;5:3-5.

\section{WriteClick ${ }^{\circledR}$ rapid online correspondence}

The editors encourage comments about recent articles through WriteClick:

Go to Neurology.org and click on the "WriteClick" tab at the top of the page. Responses will be posted within 72 hours of submission.

Before using WriteClick, remember the following:

- WriteClick is restricted to comments about studies published in Neurology within the last eight weeks

- Read previously posted comments; redundant comments will not be posted

- Your submission must be 200 words or less and have a maximum of five references; reference one must be the article on which you are commenting

- You can include a maximum of five authors (including yourself) 


\section{Neurology}

\section{Limb shaking: Video EEG report in a patient with neurolupus but no carotid stenosis}

Natalia M. Moll, Karine Mazodier, Fabrice Bartolomei, et al.

Neurology 2016;87;1846-1847

DOI 10.1212/WNL.0000000000003269

This information is current as of October 24, 2016

\begin{tabular}{|c|c|}
\hline $\begin{array}{l}\text { Updated Information \& } \\
\text { Services }\end{array}$ & $\begin{array}{l}\text { including high resolution figures, can be found at: } \\
\text { http://n.neurology.org/content/87/17/1846.full }\end{array}$ \\
\hline Supplementary Material & $\begin{array}{l}\text { Supplementary material can be found at: } \\
\text { http://n.neurology.org/content/suppl/2016/10/24/WNL.0000000000003 } \\
\text { 269.DC1 }\end{array}$ \\
\hline References & $\begin{array}{l}\text { This article cites } 2 \text { articles, } 1 \text { of which you can access for free at: } \\
\text { http://n.neurology.org/content/87/17/1846.full\#ref-list-1 }\end{array}$ \\
\hline Subspecialty Collections & $\begin{array}{l}\text { This article, along with others on similar topics, appears in the } \\
\text { following collection/s): } \\
\text { EEG; see Epilepsy/Seizures } \\
\text { http://n.neurology.org/cgi/collection/eeg_see_epilepsy-seizures } \\
\text { Lupus } \\
\text { http://n.neurology.org/cgi/collection/lupus } \\
\text { Myoclonus } \\
\text { http://n.neurology.org/cgi/collection/myoclonus } \\
\text { Other cerebrovascular disease/Stroke } \\
\text { http://n.neurology.org/cgi/collection/other_cerebrovascular_disease_st } \\
\text { roke }\end{array}$ \\
\hline Permissions \& Licensing & $\begin{array}{l}\text { Information about reproducing this article in parts (figures,tables) or in } \\
\text { its entirety can be found online at: } \\
\text { http://www.neurology.org/about/about_the_journal\#permissions }\end{array}$ \\
\hline Reprints & $\begin{array}{l}\text { Information about ordering reprints can be found online: } \\
\text { http://n.neurology.org/subscribers/advertise }\end{array}$ \\
\hline
\end{tabular}

Neurology ${ }^{\circledR}$ is the official journal of the American Academy of Neurology. Published continuously since 1951, it is now a weekly with 48 issues per year. Copyright (O 2016 American Academy of Neurology. All rights reserved. Print ISSN: 0028-3878. Online ISSN: 1526-632X.

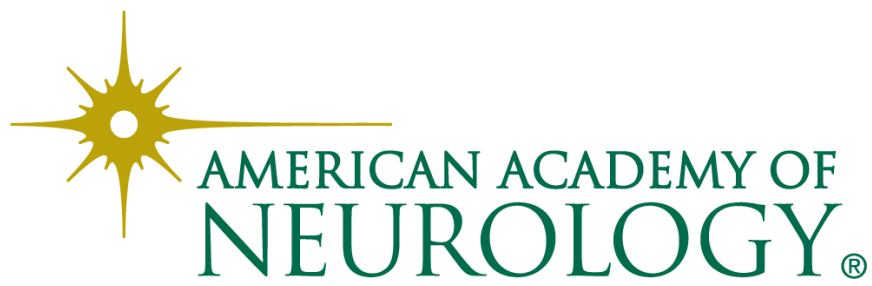

